\title{
Clinical course and predictive factors for cyclosporin-induced autologous graft-versus-host disease after autologous haematopoietic stem cell transplantation
}

\author{
Frédéric Baron, ${ }^{1}$ André Gothot, ${ }^{2}$ Jean-Paul Salmon, ${ }^{1}$ Jean-Philippe Hermanne, ${ }^{1}$ Gérald E. Pierard, ${ }^{3}$ \\ Georges Fillet ${ }^{1}$ and Yves Beguin ${ }^{1}{ }^{1}$ Department of Medicine, Division of Haematology, Department of Clinical \\ Biology, ${ }^{2}$ Division of Laboratory Haematology and ${ }^{3}$ Department of Dermatopathology, University of Liège, Liège, Belgium
}

Received 30 May 2000; accepted for publication 18 August 2000

\begin{abstract}
Summary. The administration of cyclosporin A (CyA) after autologous haematopoietic stem cell transplantation (HSCT) induces a systemic autoimmune syndrome mimicking graftvs.-host disease (GVHD). This syndrome, termed autologous GVHD has notable anti-tumour activity in animal studies. We intended to induce autologous GVHD with CyA in patients undergoing an autologous HSCT. We prospectively studied 118 patients with miscellaneous malignancies undergoing an autologous HSCT with low-dose CyA to characterize the clinical syndrome, its frequency and clinical course, and to determine the factors affecting its incidence. Patients received CyA from $\mathrm{d}-1$ through to d 28 , first starting at $2 \mathrm{mg} / \mathrm{kg}$ intravenously and then orally as soon as feasible. The dose was adjusted to achieve predose blood levels around $100 \mathrm{ng} / \mathrm{ml}$. A skin biopsy was performed when a skin rash was observed. Thirty-three percent of the patients developed clinical GVHD: clinical stage 1 in 21 patients, stage 2 in seven patients, and stage 3 in three patients. Although total body irradiation (TBI) or high-dose cyclophosphamide were previously thought to be needed, autologous GVHD occurred in five out of 12
\end{abstract}

patients $(42 \%)$ after a preparative regimen with high-dose melphalan alone. Autologous GVHD was significantly more frequent in patients older than 33 years, in patients who had received high doses of granulocyte-macrophage colony forming units (CFU-GM) and in those with a diagnosis of myeloid malignancy, compared with those with lymphoid malignancies or solid tumours. A significant negative association was also found with HLA-DR6. In lymphoma patients, GVHD occurred more frequently in advanced disease than in first or second complete remission (CR12 ) patients. All other factors studied were not predictive for GVHD. In conclusion, CyA-induced GVHD is reproducibly and safely induced with doses of CyA adapted to achieve blood levels around $100 \mathrm{ng} / \mathrm{ml}$. In retrospective analysis, there was no survival advantage for patients with GVHD. Phase III trials with this approach are needed to evaluate its anti-tumoral effect.

Keywords: autologous HSCT, autologous GVHD, GVHD, cyclosporin.
Graft-vs.-host disease (GVHD) is a major cause of death after allogeneic haematopoietic stem cell transplantation (allo-HSCT). However, it is associated with substantial antitumour activity (Weiden et al, 1979, 1981). This antitumoral effect, termed graft-vs.-leukaemia effect (GVL), was confirmed by a large retrospective study (Horowitz et al, 1990) showing a lower rate of relapse after allogeneic HSCT in patients with clinical GVHD [particularly chronic GVHD in acute myeloid leukaemia (AML) and chronic myeloid leukaemia (CML) patients and acute GVHD in acute

Correspondence: Yves Beguin, MD, University of Liège, Department of Haematology, CHU Sart-Tilman, 4000 Liège, Belgium. E-mail: yves. beguin@chu.ulg.ac.be lymphoblastic leukaemia (ALL) patients] and by the ability of donor lymphocyte infusions (DLIs) to induce complete remissions in patients relapsing after allo-HSCT (Baron \& Beguin, 2000). A graft-vs.-tumour effect has also been evidenced in multiple myeloma (Verdonck et al, 1996; Bertz et al, 1997) and breast cancer (Eibl et al, 1996). The procedure-related toxicity and mortality are lower after autologous haematopoietic stem cell transplantation (autoHSCT) than after allo-HSCT. However, auto-HSCT is associated with a high relapse rate owing, at least in part, to the absence of a graft-vs.-tumour effect associated with GVHD (Gale \& Champlin, 1984; Kersey et al, 1987).

Although histocompatibility differences are thought to initiate the anti-host response of the graft, a syndrome with 


\section{F. Baron et al}

pathology identical to GVHD can occur after autologous bone marrow transplantation (BMT) (Thien et al, 1981). This syndrome, termed autologous or syngeneic GVHD, occurs spontaneously in $5-10 \%$ of patients receiving an autologous or syngeneic HSCT (Hood et al, 1987; Byrne et al, 1997) and may be induced by the administration of cyclosporin A (CyA) after autologous HSCT in animals (Glazier et al, 1983; Bryson et al, 1989) and humans (Jones et al, 1989; Talbot et al, 1990; Carella et al, 1991; Kennedy et al, 1993; Yeager et al, 1993; Pati et al, 1996; Giralt et al, 1997; Gruhn et al, 1998). This syndrome has notable antitumour activity in animal studies (Geller et al, 1989; Charak et al, 1992a; Bryson et al, 1999) and there is also some indication of an anti-tumour effect in humans (Byrne et al, 1997). We prospectively studied 118 patients undergoing an autologous HSCT with low-dose CyA to characterize the clinical syndrome, its frequency and clinical course, as well as to determine the factors affecting its incidence, including HLA typing.

\section{PATIENTS AND METHODS}

Patients. One hundred and eighteen patients undergoing an autologous HSCT between December 1993 and October 1997 received CyA in order to induce autologous GVHD. Of these 118 patients, eight had an inadequate follow-up and 13 received CyA for less than $14 \mathrm{~d}$ (no drug prescription in one patient, patient refusal in one and early regimen-related or infectious complications in 11 patients). These complications were unrelated to $\mathrm{CyA}$, but their resolution was thought to be potentially delayed by $\mathrm{CyA}$, which was thus stopped. Thus, 97 patients, 38 men and 59 women, aged $47 \pm 14$ years (range 3-66 years, including eight children) were fully evaluable. Their diagnoses were multiple myeloma $(n=18)$, non-Hodgkin's lymphoma (NHL; $n=14$ ), Hodgkin's disease $(n=8)$, AML $(n=7)$, CML $(n=4)$, myelodysplastic syndrome (MDS; $n=2)$, breast cancer $(n=35)$ or other solid tumours $(n=9)$. The protocol was approved by the Ethics Committee at the University of Liège and patients gave consent to participate in the study.

Chemotherapy, transplant and supportive care. The conditioning regimens were STAMP V (cyclophosphamide, thiotepa, carboplatin) (Antman et al, 1992) in 35 patients, BEAM [BCNU (carmustine), etoposide, cytarabine, melphalan] in 14 patients, melphalan in 12 patients, total body irradiation (TBI) and cyclophosphamide \pm Ara-C in 15 patients, TBI and melphalan in four patients, busulphan and cyclophosphamide or other drugs in seven patients, as well as miscellaneous regimens including TBI $(n=2)$, cyclophosphamide $(n=3)$ or melphalan $(n=5)$. Patients were grafted with peripheral blood stem cells and 88 of them received granulocyte colony stimulating factor (G-CSF) to accelerate neutrophil recovery.

Induction of autologous GVHD. Patients received CyA from $\mathrm{d}-1$ through to $\mathrm{d} 28$, first as an intravenous (i.v.) $12-\mathrm{h}$ infusion starting at $2 \mathrm{mg} / \mathrm{kg}$ and then orally in one or two doses as soon as feasible. CyA levels were measured by a commercially available radioimmunoassay. CyA dose was adjusted to maintain pre-dose whole blood levels around
$100 \mathrm{ng} / \mathrm{ml}$. CyA was stopped early in four patients on d 14, d 18, d 24 and d 25 because of the development of grade 2 GVHD. Patients were examined daily during hospitalization and twice weekly after discharge. To confirm the diagnosis of GVHD, a punch biopsy was performed where a skin rash was observed.

Histopathological examination. Specimens were fixed in buffered formalin and embedded in paraffin. Six-micron thick sections were stained using haematoxylin and eosin. Histopathological grading of cutaneous GVHD was based following Lerner's classification (Lerner et al, 1974). Previous works have revealed that immunohistochemistry may be valuable in increasing the sensitivity to detect early changes of cutaneous GVHD (Pimpinelli et al, 1993; Pierard et al, 1998a, 1998b; Hermans-Le et al, 1999). In particular, keratinocytes overexpress the L1 protein and dermal dendrocytes are increased in size and number. Hence, the three-step avidin-biotin method was applied using the Mac 387 (1:100, Dakopatts, Copenhagen, Denmark), UCLH-1 (1:100, Dakopatts) and anti-factor XIIIa (1:300, Behring, Marburg, Germany) antibodies aiming at detecting intracellular L1 protein (monocytes-macrophages and altered keratinocytes), CD45R0 (T lymphocytes) and factor XIIIa (dendrocytes) respectively. After rinsing in Tris-buffered saline, sections were covered with alkaline phosphataseconjugated streptavidin (LSAB + kit prediluted, Dakopatts). New Fuschin (Dakopatts) was used as a chromogen for 5 min. Sections were counterstained with haematoxylin and mounted in glycergel (Dakopatts). The slides were reviewed by two experienced dermatopathologists.

Statistical analysis. Potential predictive factors for autologous GVHD analysed included daily or total dose and duration of i.v. or oral CyA, CyA blood levels, age, sex, diagnosis, disease status at transplant, conditioning regimen, first or second transplant, CD34 selection, cell dose [nucleated cells $(\mathrm{NC})$, granulocyte-macrophage colony forming units (CFU-GM), erythroid burst-forming units (BFU-E), mixed lineage CFU (CFU-Mix), CD $34^{+}$cells], use of G-CSF, speed of neutrophil, platelet and erythroid engraftment, and HLA A, B and DR typing.

Univariate comparison of the rate of autologous GVHD in different groups was performed by the Chi square test or Fisher's exact test, where appropriate, using Graphpad Prism (Graphpad software, San Diego, CA, USA). Multivariate analysis by stepwise logistic regression was performed with SAS (SAS Institute, Cary, NC, USA). Actuarial survival analyses were performed in Prism using the Kaplan-Meier product-limit method. Comparisons between survival curves were performed using the log-rank test.

\section{RESULTS}

Overall results

Thirty-two patients (33\%) developed clinical GVHD (Tables I and II). This syndrome occurred 4-33 d (median $19 \mathrm{~d}$ ) following HSCT and persisted for 2-27 d (median $8 \mathrm{~d}$ ). Mean doses of i.v. and oral CyA administered were $2 \cdot 11 \pm$ $0.78 \mathrm{mg} / \mathrm{kg} / \mathrm{d}$ (range $0 \cdot 76-5.95$ ) and $2 \cdot 15 \pm 1.29 \mathrm{mg} /$ $\mathrm{kg} / \mathrm{d}$ (range 0.65-9.38) respectively. Thirty-seven patients 
Table I. Clinical autologous GVHD according to the underlying disease.

\begin{tabular}{|c|c|c|c|c|c|c|c|c|}
\hline \multirow[t]{2}{*}{ Underlying disease } & \multirow{2}{*}{$\begin{array}{l}\text { Number of patients with GVHD } \\
\text { /total number of patients } \\
(\%)\end{array}$} & \multicolumn{3}{|c|}{$\begin{array}{l}\text { Number of patients with } \\
\text { cutaneous GVHD }\end{array}$} & \multirow{2}{*}{$\begin{array}{l}\text { Number of patients with } \\
\text { digestive GVHD } \\
\text { Stage } 1\end{array}$} & \multicolumn{3}{|c|}{$\begin{array}{l}\text { Number of patients } \\
\text { with overall GVHD }\end{array}$} \\
\hline & & Stage 1 & Stage 2 & Stage 3 & & Stage 1 & Stage 2 & Stage 3 \\
\hline Multiple myeloma & $6 / 18(33 \%)$ & 4 & 2 & 0 & 1 & 5 & 1 & 0 \\
\hline NHL & $3 / 14(21 \%)$ & 2 & 0 & 1 & 1 & 2 & 1 & 0 \\
\hline Hodgkin's disease & $4 / 8(50 \%)$ & 3 & 1 & 0 & 0 & 4 & 0 & 0 \\
\hline AML & $4 / 7(57 \%)$ & 3 & 1 & 0 & 0 & 4 & 0 & 0 \\
\hline CML & $2 / 4(50 \%)$ & 1 & 0 & 1 & 1 & 0 & 2 & 0 \\
\hline MDS & $2 / 2(100 \%)$ & 1 & 1 & 0 & 0 & 2 & 0 & 0 \\
\hline Breast cancer & $11 / 35(31 \%)$ & 7 & 2 & 1 & 1 & 9 & 2 & 0 \\
\hline Soft tissue sarcoma & $0 / 4(0 \%)$ & 0 & 0 & 0 & 0 & 0 & 0 & 0 \\
\hline Neuroblastoma & $0 / 2(0 \%)$ & 0 & 0 & 0 & 0 & 0 & 0 & 0 \\
\hline Ovarian cancer & $0 / 1(0 \%)$ & 0 & 0 & 0 & 0 & 0 & 0 & 0 \\
\hline Testicular cancer & $0 / 2(0 \%)$ & 0 & 0 & 0 & 0 & 0 & 0 & 0 \\
\hline Total & $32 / 97(33 \%)$ & 21 & 7 & 3 & 4 & 26 & 6 & 0 \\
\hline
\end{tabular}

developed a skin rash and the skin biopsy confirmed cutaneous GVHD in 31 of them. According to Glucksberg criteria (Thomas et al, 1975), the clinical stage was 1 in 21 patients, 2 in seven patients and 3 in three patients. The rash did not involve any particular part of the body. Four patients developed clinical stage 1 gastrointestinal GVHD. This gastrointestinal GVHD was isolated in one patient, but was associated with cutaneous GVHD in the other three patients. This was confirmed by biopsies in two patients. No patient developed liver GVHD. GVHD was spontaneously reversible in 28 patients and resolved after premature withdrawal of CyA in three patients and with a short course of corticosteroids in addition to withdrawal of $\mathrm{CyA}$ in one patient. Alternatively, among the 11 patients receiving CyA for less than $14 \mathrm{~d}$ because of early complications and thus not fully evaluable, four additional patients developed a skin rash, which corresponded to GVHD in two of them.
Predictive factors

Univariate analysis of potential predictive factors showed that autologous GVHD was significantly more frequent in patients older than 33 years $(38 \%$ vs. $13 \%$ in younger patients, $P=0 \cdot 043$ ) and in patients with a diagnosis of myeloid malignancy (62\%) compared with those with lymphoid malignancies (32\%) or solid tumours $(25 \%)$ $(P=0 \cdot 048)$. A significant negative association was also found with HLA-A10 (12\% vs. $38 \%$ of patients without HLA-A10, $P=0.049)$ and HLA-B16 $(0 \%$ vs. $37 \%$ in patients without HLA-B16) $(P=0 \cdot 047)$. The presence of B16 and A10 were strongly associated in our patients $(P=0 \cdot 0001)$. All other factors studied were not predictive of GVHD in univariate analysis (Table III). Subgroup analysis showed that, in lymphoma patients, the rate of GVHD was lower in first or second complete remission (CR1-2) (one out of 11 or $9 \%$ ) than in more advanced

Table II. Clinical autologous GVHD according to the conditioning regimen.

\begin{tabular}{lcc}
\hline Conditioning regimen & Number of patients & Number (\%) of patients with GVHD \\
\hline STAMP V & 5 & $11(31 \%)$ \\
BEAM & 14 & $4(29 \%)$ \\
Mel & 12 & $5(42 \%)$ \\
Cy + Ara-C + TBI & 8 & $5(63 \%)$ \\
Cy + TBI & 7 & $2(29 \%)$ \\
Mel + TBI & 4 & $1(25 \%)$ \\
Bu + Cy & 4 & $2(50 \%)$ \\
Bu + others & 3 & $0(0 \%)$ \\
TBI + others & 2 & $1(50 \%)$ \\
Cy + others & 3 & $1(33 \%)$ \\
Mel + others & 5 & $0(0 \%)$
\end{tabular}

STAMP V, cyclophosphamide, thiotepa and carboplatin; BEAM, BCNU, etoposide, cytarabine and melphalan; Mel, melphalan; Cy, cyclophosphamide; Ara-C, cytarabine; TBI, total body irradiation; $\mathrm{Bu}$, busulphan. 


\section{F. Baron et al}

Table III. Predictive factors of CyA-induced autologous GVHD.

\begin{tabular}{|c|c|c|c|c|}
\hline Predictive factor & & Number of patients & $\%$ with GVHD & $P$-value \\
\hline \multirow[t]{2}{*}{ Sex: } & Male & 38 & 37 & NS \\
\hline & Female & 59 & 31 & \\
\hline \multirow[t]{2}{*}{ Age: } & $<33$ years & 19 & 11 & $0 \cdot 0430$ \\
\hline & $\geq 33$ years & 78 & 38 & \\
\hline \multirow[t]{3}{*}{ Route of CyA administration: } & orally & 14 & 36 & NS \\
\hline & i.v. & 8 & 50 & \\
\hline & orally + i.v. & 75 & 31 & \\
\hline \multirow[t]{3}{*}{ Average total dose of CyA: } & $<45 \mathrm{mg} / \mathrm{kg}$ & 30 & 42 & NS \\
\hline & $45-65 \mathrm{mg} / \mathrm{kg}$ & 42 & 21 & \\
\hline & $>65 \mathrm{mg} / \mathrm{kg}$ & 25 & 36 & \\
\hline \multirow[t]{3}{*}{ Average daily dose of CyA: } & $<1.5 \mathrm{mg} / \mathrm{kg}$ & 30 & 33 & NS \\
\hline & $1 \cdot 6-2 \cdot 0 \mathrm{mg} / \mathrm{kg}$ & 31 & 32 & \\
\hline & $>2.0 \mathrm{mg} / \mathrm{kg}$ & 36 & 33 & \\
\hline \multirow[t]{3}{*}{ Average pre-dose CyA blood levels: } & $<100 \mathrm{ng} / \mathrm{ml}$ & 39 & 28 & NS \\
\hline & $100-120 \mathrm{ng} / \mathrm{ml}$ & 28 & 39 & \\
\hline & $>120 \mathrm{ng} / \mathrm{ml}$ & 30 & 33 & \\
\hline \multirow[t]{3}{*}{ Disease: } & Myeloid malignancies & 13 & 62 & $0 \cdot 0481$ \\
\hline & Lymphoid malignancies & 40 & 32 & \\
\hline & Solid tumours & 44 & 25 & \\
\hline \multirow[t]{2}{*}{ Conditioning regimen: } & TBI & 21 & 43 & NS \\
\hline & No TBI & 76 & 30 & \\
\hline \multirow[t]{2}{*}{ Consecutive number of transplant: } & First & 91 & 34 & NS \\
\hline & Second & 6 & 17 & \\
\hline \multirow[t]{2}{*}{ CD34 selection: } & Yes & 15 & 20 & NS \\
\hline & No & 82 & 35 & \\
\hline \multicolumn{5}{|l|}{ Cell dose } \\
\hline \multirow[t]{4}{*}{ NC: } & $<0.510^{8} / \mathrm{kg}$ & 15 & 20 & NS \\
\hline & $0 \cdot 5-310^{8} / \mathrm{kg}$ & 23 & 48 & \\
\hline & $3-510^{8} / \mathrm{kg}$ & 31 & 35 & \\
\hline & $>510^{8} / \mathrm{kg}$ & 28 & 25 & \\
\hline \multirow[t]{2}{*}{ CFU-GM: } & $<10010^{4} / \mathrm{kg}$ & 58 & 29 & NS \\
\hline & $>10010^{4} / \mathrm{kg}$ & 39 & 38 & \\
\hline \multirow[t]{3}{*}{ BFU-E: } & $<4010^{4} / \mathrm{kg}$ & 33 & 27 & NS \\
\hline & $40-15010^{4} / \mathrm{kg}$ & 28 & 39 & \\
\hline & $>15010^{4} / \mathrm{kg}$ & 36 & 34 & \\
\hline \multirow[t]{3}{*}{ CFU-mix: } & $<410^{4} / \mathrm{kg}$ & 32 & 44 & NS \\
\hline & $4-2510^{4} / \mathrm{kg}$ & 33 & 21 & \\
\hline & $>2510^{4} / \mathrm{kg}$ & 32 & 37 & \\
\hline \multirow[t]{4}{*}{ CD $34^{+}$cells: } & $<310^{6} / \mathrm{kg}$ & 15 & 33 & NS \\
\hline & $3-510^{6} / \mathrm{kg}$ & 28 & 32 & \\
\hline & $5-1010^{6} / \mathrm{kg}$ & 27 & 33 & \\
\hline & $>1010^{6} / \mathrm{kg}$ & 27 & 36 & \\
\hline \multirow[t]{2}{*}{ G-CSF use: } & Yes & 88 & 31 & NS \\
\hline & No & 9 & 56 & \\
\hline Number of days to 500 neutrophils: & $<15$ & 85 & 29 & 0.057 (NS) \\
\hline & $>15$ & 12 & 58 & \\
\hline Number of days to $1 \%$ reticulocytes: & $<11$ & 32 & 38 & NS \\
\hline & $12-15$ & 38 & 26 & \\
\hline & $>15$ & 27 & 37 & \\
\hline Number of days to 20000 platelets: & $<10$ & 38 & 34 & NS \\
\hline & $11-15$ & 31 & 29 & \\
\hline & $16-30$ & 16 & 38 & \\
\hline & $>30$ & 12 & 33 & \\
\hline HLA A10*: & Yes & 17 & 12 & $0 \cdot 0485$ \\
\hline & No & 80 & 38 & \\
\hline B16: & Yes & 10 & 0 & $0 \cdot 0468$ \\
\hline & No & 87 & 37 & \\
\hline DR6: & Yes & 22 & 18 & NS \\
\hline & No & 75 & 37 & \\
\hline
\end{tabular}

*Other HLA subgroups were tested and found not significantly associated with autologous GVHD, including A 1, 2, 3, 9 and 19, B 5, 7, 8, 12, 15, 17, 27 and 35, and DR 1, 2, 3, 4, 5 and 7. 
A

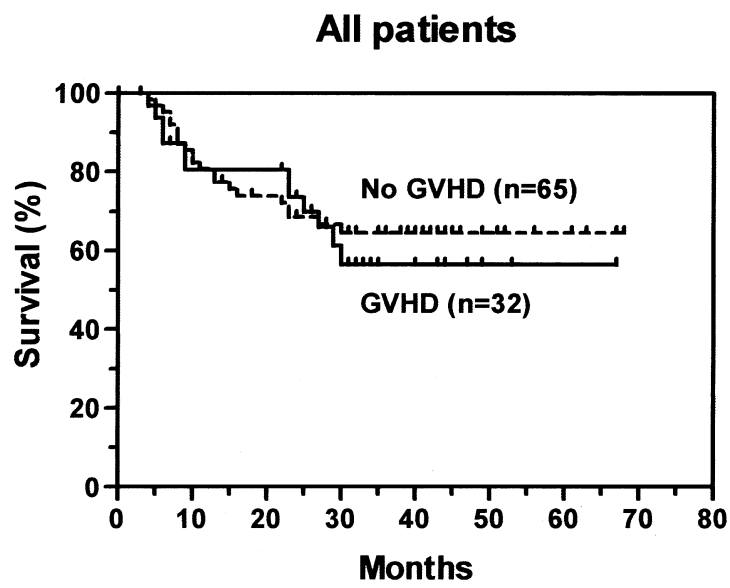

B

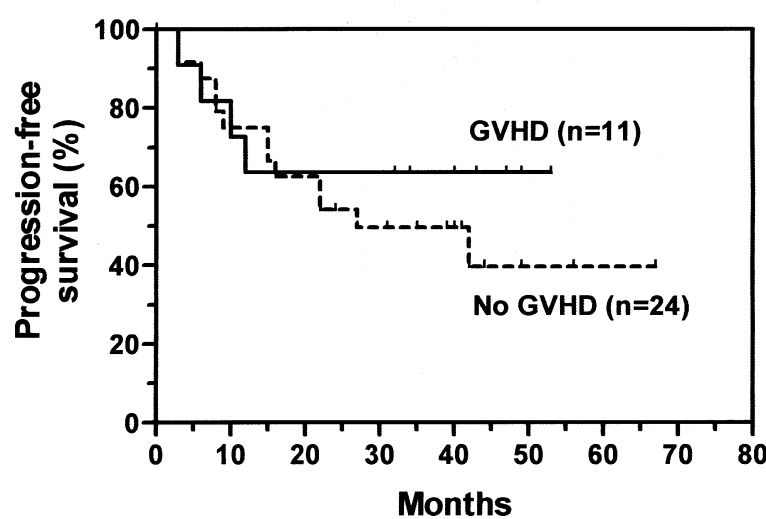

Fig 1. A. Overall survival in patients with or without autologous GVHD (NS). B. Progression-free survival in breast cancer patients with or without autologous GVHD (NS).

patients (six out of 11 or $55 \%)(P=0 \cdot 022)$. Among breast cancer patients, GVHD was as frequent in the metastatic (six out of 19) as in the adjuvant (five out of 16) setting.

Multivariate analysis by stepwise logistic regression was performed with all variables except B16 (because there were no cases of GVHD in patients with HLA-B16). Factors significantly associated with autologous GVHD were a diagnosis of myeloid malignancy compared with lymphoid malignancies or solid tumours $(P=0 \cdot 012)$, a high dose of CFU-GM infused $(P=0 \cdot 041)$ and absence of HLA-DR6 $(P=0 \cdot 041)$. Age was not found to be a significant predictor because there was some statistical interaction between age and presence of DR6 (more frequent in a young age, $P=0 \cdot 046)$.

Toxicity associated with autologous GVHD

Patients were prospectively monitored for haematopoietic recovery, regimen-related toxicities, infections and other complications, as well as for bilirubin and creatinine levels. Trilineage haematopoietic recovery and platelet or red blood cell $(\mathrm{RBC})$ transfusion rates were similar in patients with or without autologous GVHD. There was no significant increase in any toxicity parameter associated with the development of autologous GVHD: grade 1 or 2 liver toxicity occurred in 24 out of 65 (37\%) patients without GVHD vs. eight out of $32(25 \%)$ patients with autologous GVHD; grade 1 or 2 mucositis occurred in 26 out of $65(40 \%)$ patients without GVHD vs. 14 out of 32 (44\%) patients with autologous GVHD; and grade 1 or 2 gastrointestinal toxicity occurred in 21 out of 65 (32\%) patients and eight out of 32 $(25 \%)$ patients respectively. Peak bilirubin or creatinine values were comparable in the two groups. There was no case of thrombotic thrombocytopenic purpura or any death within $50 \mathrm{~d}$ of transplant in the 97 patients studied. Fever occurred in 16 of the 32 patients $(50 \%)$ with GVHD and in 39 of the 65 patients $(60 \%)$ without GVHD (not significant; NS). The number of days with fever or with i.v. antibiotics did not differ. Finally, the occurrence of autologous GVHD did not affect neutrophil or lymphocyte counts, or serum creatinine, but elevated serum bilirubin levels occurred more frequently in patients with stage 2 GVHD (three out of six) than in those with stage 1 GVHD (nine out of 26) or no GVHD (21 out of 65) (NS).

\section{Long-term outcome}

Overall survival of patients with GVHD ( $57 \%$ at 5 years) or without GVHD $(65 \%$ at 5 years $)$ was not significantly different (Fig 1). However, this analysis involved patients with a variety of diagnoses and disease status at transplant. Separate analyses of patients with lymphoma, multiple myeloma or leukaemia did not show significant differences in survival according to occurrence of autologous GVHD. However, these subgroups were heterogeneous and the balance between good-risk and high-risk patients with or without GVHD was not achieved. This was only obtained among patients with breast cancer: progression-free survival at 4 years was $64 \%$ in patients with GVHD and $40 \%$ in those without GVHD (NS).

\section{DISCUSSION}

Animal studies have shown that CyA treatment induced a failure of T-cell differentiation, as well as autologous or syngeneic GVHD associated with the development of autoreactive $\mathrm{CD}^{+}$cytotoxic $\mathrm{T}$ cells (Hess et al, 1985, 1994; Hess \& Thoburn, 1997). In vitro lysis of a myeloma cell line by $\mathrm{CD}^{+}$splenic $\mathrm{T}$ cells from Lou $\mathrm{M}$ rats that developed syngeneic GVHD has been demonstrated (Geller et al, 1989). In vivo, a significant anti-tumour effect of syngeneic GVHD was evidenced and enhanced by interferon (IFN)- $\gamma$ (Noga et al, 1992). Another study in mice demonstrated synergy between CyA and interleukin (IL)-2 in causing regression of lung metastases and improving survival of animals with either melanoma or AML (Charak et al, 1992b).

A few clinical studies have been performed in patients with lymphoma (Jones et al, 1989; Vogelsang et al, 1989; Carella et al, 1991; Pati et al, 1996; Gryn et al, 1997), AML (Talbot et al, 1990; Yeager et al, 1992, 1993; Gruhn et al, 1998), myeloma (Giralt et al, 1997), breast cancer 
Table IV. Major clinical studies of CyA-induced autologous GVHD.

\begin{tabular}{|c|c|c|c|c|c|c|}
\hline Study & Number & $\begin{array}{l}\text { Underlying } \\
\text { disease }\end{array}$ & $\begin{array}{l}\text { Conditioning } \\
\text { regimen }\end{array}$ & Dose of CyA & $\begin{array}{l}\% \text { of patients with } \\
\text { pathological GVHD }\end{array}$ & $\begin{array}{l}\% \text { of patients with } \\
\text { clinical GVHD }\end{array}$ \\
\hline Yeager et al (1992) & 19 & AML & $\mathrm{Bu}+\mathrm{Cy}$ & $\begin{array}{l}1 \mathrm{mg} / \mathrm{kg} \text { i.v. }(n=7) \\
2 \cdot 5 \mathrm{mg} / \mathrm{kg} \text { i.v. }(n=8) \\
3 \cdot 75 \mathrm{mg} / \mathrm{kg} \text { i.v. }(n=4)\end{array}$ & 79 & 53 \\
\hline Giralt et al (1997) & 14 & $\begin{array}{l}\text { Multiple } \\
\text { myeloma }\end{array}$ & $\begin{array}{l}\mathrm{Bu}+\mathrm{Cy}+ \\
\text { Thiot }\end{array}$ & $\begin{array}{l}\text { i.v. CyA with blood levels: } \\
50-150 \mathrm{ng} / \mathrm{ml}(n=7) \\
150-300 \mathrm{ng} / \mathrm{ml}(n=7)\end{array}$ & $\begin{array}{l}57 \\
43\end{array}$ & $\begin{array}{l}7 \\
0\end{array}$ \\
\hline Kennedy et al (1993) & 51 & Breast cancer & $\mathrm{Cy}+$ Thio & $\begin{array}{l}1 \mathrm{mg} / \mathrm{kg} \text { i.v. }(n=7) \\
2.5 \mathrm{mg} / \mathrm{kg} \text { i.v. }(n=31) \\
3.75 \mathrm{mg} / \mathrm{kg} \text { i.v. }(n=13)\end{array}$ & $\begin{array}{l}14 \\
68 \\
92\end{array}$ & $\begin{array}{l}14 \\
52 \\
83\end{array}$ \\
\hline Gruhn et al (1998) & 20 & AML, ALL, NHL & Miscellaneous & $1.5 \mathrm{mg} / \mathrm{kg}$ i.v. & 50 & 25 \\
\hline Baron \& Beguin (2000) & 97 & Miscellaneous & Miscellaneous & $\begin{array}{l}\text { i.v. or oral CyA with blood } \\
\text { levels around } 100 \mathrm{ng} / \mathrm{ml}\end{array}$ & - & 33 \\
\hline
\end{tabular}

AML, acute myeloid leukaemia; ALL, acute lymphoid leukaemia; NHL, non-Hodgkin’s lymphoma; Bu, busulphan; Cy, cyclophosphamide; Thiot, thiothepa; CyA, cyclosporin A.

(Kennedy et al, 1993, 1994), ALL (Carella et al, 1991; Gruhn et al, 1998) and CML (Carella et al, 1991). The frequency of pathological and clinical autologous GVHD in the five major studies is showed in Table IV. The number of patients with myeloma and breast cancer in our study was comparable to that of previous studies reporting trials in a single disease (Kennedy et al, 1993; Giralt et al, 1997). Among studies there were important discrepancies between rates of clinical and pathological GVHD, some showing similar rates and some a much lower incidence of clinical vs. pathological GVHD. The distinction between clinical and only pathological autologous GVHD may be of importance because, in allogeneic HSCT, only clinical GVHD has been shown to be associated with an anti-tumour effect. Therefore, we focused on clinical GVHD and elected not to perform systematic skin biopsies in the absence of any skin rash.

The diagnosis of skin eruptions developing after HSCT requires close clinicopathological correlation because other skin rashes histologically resemble GVHD (Johnson \& Farmer, 1998). The positive Lerner's criteria for GVHD (Lerner et al, 1974) are used in our practice in combination with exclusion criteria and immunohistochemical assessment to refine the diagnosis. Positive immunohistochemical criteria for GVHD include the overexpression of the L1 protein in keratinocytes and hyperplasia of the dendrocyte population (Pierard et al, 1998a, 1998b; Hermans-Le et al, 1999). In contrast, disordered epidermal maturation, superficial dyskeratotic keratinocytes and normal dendrocytes suggest a cytotoxic effect of chemotherapy. Vasculitis, eosinophils, dendrocytoclasia and variable L1-protein load in keratinocytes favour a drug reaction. Viral exanthemas only marginally affect the dendrocyte population and the pattern of L1-protein labelling. Finally, the eruption of lymphocyte recovery is almost indistinguishable from lowgrade allogeneic reactions although the L1-protein expression in the epidermis does not appear to be boosted at the same level.
As in previous studies, clinical autologous GVHD in our study was generally self-limited and mostly confined to the skin. However, clinical gastrointestinal GVHD may have occurred in very few patients and serum bilirubin levels tended to be more frequently elevated (although not reaching levels characteristic of stage 1 liver GVHD) in patients with stage 2 GVHD (three out of six) compared with those with stage 1 GVHD (nine out of 26) or no GVHD (21 out of 65 ), suggesting that mild liver GVHD may also be a feature of autologous GVHD.

The global occurrence of clinical autologous GVHD in our study was $33 \%$ (57\% in AML patients). This is in concordance with Yeager et al (1992) (53\% in AML patients) and Kennedy et al (1993) (Table IV). As yet, the only known predictive factor of autologous GVHD occurrence in humans has been the dose of CyA in patients with breast cancer (Kennedy et al, 1993), although this finding was not confirmed in this or two other studies (Yeager et al, 1992; Giralt et al, 1997). As a fixed dose of CyA may be associated with high CyA blood levels in some patients, we chose to adapt the dose to obtain pre-dose blood levels around $100 \mathrm{ng} / \mathrm{ml}$ and the dose necessary to achieve this varied considerably. However, the rate of autologous GVHD was not influenced by the dose given or by CyA blood levels.

The strongest predictive factor in multivariate analysis was a diagnosis of myeloid malignancy vs. a diagnosis of lymphoid malignancy or solid tumour. This confirmed what could be suspected from previous studies (Table IV) and could relate to differences in preparative regimens used in these three groups of diseases, as well as alterations of thymic function and/or of $\mathrm{T}$ cells in the graft owing to the underlying disease and previous chemotherapy. For instance, the incidence of GVHD was lower in lymphoma patients in CR1-2 than in more advanced patients. In patients with multiple myeloma, the rate of clinical autologous GVHD was 33\% (higher than the $7 \%$ observed in another study (Giralt et al, 1997)), thus denying a role for 
T-cell dysfunction in the low incidence of clinical autologous GVHD previously reported.

Induction of autologous GVHD in man was thought to require either TBI or Cy in the preparative regimen (Jones et al, 1989; Hess \& Thoburn, 1997). We report here for the first time that CyA can also induce autologous GVHD after a preparative regimen with high-dose melphalan alone in $42 \%$ of patients with multiple myeloma. This finding may permit the development of new strategies of post-transplant immunotherapy, for example combining CyA with interferon, in this still incurable disease. Indeed, interferon gamma has been shown to augment the probability of CyAinduced autologous GVHD in animal (Charak et al, 1992a; Noga et al, 1992), as well as human (Kennedy et al, 1994; Gryn et al, 1997), studies, but there is little experience with interferon alpha to date.

Another predictive factor evidenced in our study was the age of the patients: the incidence of autologous GVHD was lower in children than in adults, as is the case after allogeneic GVHD (Ramsay et al, 1982). Age was not retained as a predictive factor in multivariate analysis because of statistical interaction between age and HLA-DR6 (HLA-DR6 more frequent in young patients), the latter being entered first in the model.

The dose of CFU-GM infused had a significant impact upon the rate of autologous GVHD, although the dose of nucleated cells or mononucleated cells did not. This may signify that lymphocytes or monocytes in the graft are not primarily responsible for the syndrome that is caused by cells newly produced from transplanted haematopoietic stem cells.

We also found a significant association between some HLA subgroups and occurrence of autologous GVHD: autologous GVHD was significantly more frequent in patients without HLA-DR6 (or without B16). $\mathrm{CD}^{+} \mathrm{T}$ cells responsible for autologous GVHD recognize MHC class II antigens in combination with a peptide from the invariant chain (Hess \& Thoburn, 1997). Further studies are needed to determine whether some HLA class II antigens are more or less susceptible to recognition by such $\mathrm{CD}^{+} \mathrm{T}$ cells. However, this association may also just be a chance finding when examining a large set of HLA subgroups, as no particular HLA class I or II antigen has been shown to be more prone to cause either acute or chronic GVHD in the allogeneic setting (Martin et al, 1998).

The aim of this trial was to characterize the clinical GVHD syndrome and determine factors affecting its incidence. Therefore, patients with a variety of ages, diseases and conditioning regimens were included. However, the final purpose of administering CyA is not to induce autologous GVHD, but to improve disease-free survival. A retrospective analysis of our patients did not show a survival advantage for those patients presenting with autologous GVHD. However, our group of patients was heterogeneous as far as the primary diagnoses and disease status were concerned, therefore precluding any final conclusion on the clinical impact of autologous GVHD on tumour control. The largest group of patients with breast cancer was the only one clearly well-balanced between high (metastatic) and standard (adjuvant) risks. There was a trend towards a better progression-free survival (PFS) beyond 2 years in patients with GVHD, but this was not statistically significant. Longer follow-up is needed to clarify this critical issue. It is now necessary to carry out prospective randomised studies of autologous GVHD induction by cyclosporin in well-defined groups of subjects, particularly in high-risk breast cancer patients. These studies will need to be multicentric and a common approach to the diagnosis of autologous GVHD will be critical.

\section{ACKNOWLEDGMENTS}

Frédéric Baron is Research Assistant, André Gothot is Senior Research Assistant and Yves Beguin is Research Director of the National Fund for Scientific Research (FNRS, Belgium).

\section{REFERENCES}

Antman, K., Ayash, L., Elias, A., Wheeler, C., Hunt, M., Eder, J.P., Teicher, B.A., Critchlow, J., Bibbo, J. \& Schnipper, L.E. (1992) A phase II study of high-dose cyclophosphamide, thiotepa, and carboplatin with autologous marrow support in women with measurable advanced breast cancer responding to standard-dose therapy. Journal of Clinical Oncology, 10, 102-110.

Baron, F. \& Beguin, Y. (2000) Adoptive immunotherapy with donor lymphocyte infusions after allogeneic HPC transplantation. Transfusion, 40, 468-476.

Bertz, H., Burger, J.A., Kunzmann, R., Mertelsmann, R. \& Finke, J. (1997) Adoptive immunotherapy for relapsed multiple myeloma after allogeneic bone marrow transplantation (BMT): evidence for a graft-versus-myeloma effect. Leukemia, 11, 281-283.

Bryson, J.S., Jennings, C.D., Caywood, B.E. \& Kaplan, A.M. (1989) Induction of a syngeneic graft-versus-host disease-like syndrome in DBA/2 mice. Transplantation, 48, 1042-1047.

Bryson, J.S., Jennings, C.D., Lowery, D., Carlson, S., Pflugh, D., Caywood, B. \& Kaplan, A.M. (1999) Rejection of an MHC class II negative tumor following induction of murine syngeneic graftversus-host disease. Bone Marrow Transplantation, 23, 363-372.

Byrne, J.L., Carter, G.I., Ellis, I., Haynes, A.P. \& Russell, N.H. (1997) Autologous GVHD following PBSCT, with evidence for a graftversus-myeloma effect. Bone Marrow Transplantation, 20, $517-$ 520.

Carella, A.M., Gaozza, E., Congiu, A., Carlier, P., Nati, S., Truini, M. \& Viale, M. (1991) Cyclosporine-induced graft-versus-host disease after autologous bone marrow transplantation in hematological malignancies. Annals of Hematology, 62, 156-159.

Charak, B.S., Sadowski, R.M. \& Mazumder, A. (1992a) Antitumor effect of interferon plus cyclosporine A following chemotherapy for disseminated melanoma. Cancer Research, 52, 6482-6486.

Charak, B.S., Agah, R. \& Mazumder, A. (1992b) Synergism of interleukin-2 and cyclosporine A in induction of a graft-versustumor effect without graft-versus-host disease after syngeneic bone marrow transplantation. Blood, 80, 179-184.

Eibl, B., Schwaighofer, H., Nachbaur, D., Marth, C., Gachter, A., Knapp, R., Bock, G., Gassner, C., Schiller, L., Petersen, F. \& Niederwieser, D. (1996) Evidence for a graft-versus-tumor effect in a patient treated with marrow ablative chemotherapy and allogeneic bone marrow transplantation for breast cancer. Blood, 88, 1501-1508.

Gale, R.P. \& Champlin, R. (1984) How does bone-marrow transplantation cure leukaemia? Lancet, 2, 28-30. 


\section{F. Baron et al}

Geller, R.B., Esa, A.H., Beschorner, W.E., Frondoza, C.G., Santos, G.W. \& Hess, A.D. (1989) Successful in vitro graft-versus-tumor effect against an Ia-bearing tumor using cyclosporine-induced syngeneic graft-versus-host disease in the rat. Blood, 74, 11651171.

Giralt, S., Weber, D., Colome, M., Dimopoulos, M., Mehra, R., Van Besien, K., Gajewski, J., Andersson, B., Khouri, I., Przepiorka, D. van Wolff, B., Delasalle, K., Korbling, M., Seong, D., Alexanian, R. \& Champlin, R. (1997) Phase I trial of cyclosporine-induced autologous graft-versus-host disease in patients with multiple myeloma undergoing high-dose chemotherapy with autologous stem-cell rescue. Journal of Clinical Oncology, 15, 667-673.

Glazier, A., Tutschka, P.J., Farmer, E.R. \& Santos, G.W. (1983) Graftversus-host disease in cyclosporine A-treated rats after syngeneic and autologous bone marrow reconstitution. Journal of Experimental Medicine, 158, 1-8.

Gruhn, B., Häfer, R., Kosmehl, H., Fuchs, D. \& Zintl, F. (1998) Cyclosporin A-induced graft-versus-host disease following autologous bone marrow and stem cell transplantation in hematological malignancies of childhood. Bone Marrow Transplantation, 21, 901-907.

Gryn, J., Johnson, E., Goldman, N., Devereux, L., Grana, G., Hageboutros, E., Fernandez, E., Constantinou, C., Harrer, W. Viner, E. \& Goldberg, J. (1997) The treatment of relapsed or refractory intermediate grade non-Hodgkin's lymphoma with autologous bone marrow transplantation followed by cyclosporine and interferon. Bone Marrow Transplantation, 19, 221-226.

Hermans-Le, T., Paquet, P., Pierard-Franchimont, C., Arrese, J.E. \& Pierard, G.E. (1999) Regulatory function of factor XIIIa-positive dendrocytes in incipient toxic epidermal necrolysis and graftversus-host reaction. A hypothesis. Dermatology, 198, 184-186.

Hess, A.D. \& Thoburn, C. (1997) Immunobiology and immunotherapeutic implications of syngeneic/autologous graft-versus-host disease. Immunological Reviews, 157, 111-123.

Hess, A.D., Horwitz, L.R., Beschorner, W.E. \& Santos, G.W. (1985) Development of graft-vs.-host disease-like syndrome in cyclosporine-treated rats after syngeneic bone marrow transplantation. I. Development of cytotoxic T lymphocytes with apparent polyclonal anti-Ia specificity, including autoreactivity. Journal of Experimental Medicine, 161, 718-730.

Hess, A.D., Fischer, A.C., Horwitz, L.R., Bright, E.C. \& Laulis, M.K. (1994) Characterization of peripheral autoregulatory mechanisms that prevent development of cyclosporin-induced syngeneic graft-versus-host disease. Journal of Immunology, 153, 400-411.

Hood, A.F., Vogelsang, G.B., Black, L.P., Farmer, E.R. \& Santos, G.W. (1987) Acute graft-versus-host disease: development following autologous and syngeneic bone marrow transplantation. Archives of Dermatology, 123, 745-750.

Horowitz, M.M., Gale, R.P., Sondel, P.M., Goldman, J.M., Kersey, J., Kolb, H.J., Rimm, A.A., Ringden, O., Rozman, C. \& Speck, B. (1990) Graft-versus-leukemia reactions after bone marrow transplantation. Blood, 75, 555-562.

Johnson, M.L. \& Farmer, E.R. (1998) Graft-versus-host reactions in dermatology. Journal of the American Acadademy of Dermatology. 38, 369-392.

Jones, R.J., Vogelsang, G.B., Hess, A.D., Farmer, E.R., Mann, R., Geller, R.B., Piantadosi, S. \& Santos, G.W. (1989) Induction of graft-versus-host disease after autologous bone marrow transplantation. Lancet, 1, 754-757.

Kennedy, M.J., Vogelsang, G.B., Beveridge, R.A., Farmer, E.R., Altomonte, V., Huelskamp, A.M. \& Davidson, N.E. (1993) Phase 1 trial of intravenous cyclosporine to induce graft-versus-host disease in women undergoing autologous bone marrow trans- plantation for breast cancer. Journal of Clinical Oncology, 11, 478484 .

Kennedy, M.J., Vogelsang, G.B., Jones, R.E., Farmer, E.R., Hess, A.D., Altomonte, V., Huelskamp, A.M. \& Davidson, N.E. (1994) Phase I trial of interferon gamma to potentiate cyclosporine-induced graft-versus-host disease in women undergoing autologous bone marrow transplantation for breast cancer. Journal of Clinical Oncology, 12, 249-257.

Kersey, J., Weisdorf, D.J., Nesbit, M.E., Lebien, T., Woods, W., McGlave, P., Kim, T., Vallera, D., Goldman, A. \& Bostrom, B. (1987) Comparison of autologous and allogeneic bone marrow transplantation for treatment of high-risk refractory acute lymphoblastic leukemia. New England Journal of Medicine, 317, 461-467.

Lerner, K.G., Kao, G.E., Storb, R., Buckner, C.D., Clift, R.A. \& Thomas, E.D. (1974) Histopathology of graft-versus-host reaction (GVHR) in human recipients of marrow from HLA-matched sibling donors. Transplantation Proceedings, 6, 367-371.

Martin, P., Gooley, T., Anasetti, C., Petersdorf, E. \& Hansen, J. (1998) HLAs and risk of acute or chronic graft-vs.-host disease after marrow transplantation from HLA-identical sibling. Biology of Blood and Marrow Transplantation, 4, 128-133.

Noga, S.J., Horwitz, L.R., Kim, H., Laulis, M.K. \& Hess, A.D. (1992) Interferon-gamma potentiates the antitumor effect of cyclosporine-induced autoimmunity. Journal of Hematotherapy, 1, 75-84.

Pati, A.R., Godder, K., Abhyankar, S.H., Gee, A. \& Henslee-Downey, P.J. (1996) Cyclosporine-induced autologous graft-versus-host disease following autologous blood stem cell transplantation for lymphoma. Bone Marrow Transplantation, 17, 1081-1083.

Pierard, G.E., Nikkels-Tassoudji, N., Arrese, J.E., Nikkels, A.F. \& Pierard-Franchimont, C. (1998a) L1-protein in incipient lymphocyte-depleted graft-versus-host disease: expression in keratinocytes and coexpression with factor XIIIa in dermal cells. Turkian Journal of Dermatopathology, 7, 10-13.

Pierard, G.E., Nikkels-Tassoudji, N., Nikkels, A.F., Arrese, J.E., Jerusalem, G., Beguin, Y. \& Fillet, G. (1998b) Epidermal calprotectin expression in lymphocyte-depleted cutaneous graftversus-host reaction. Archives of Argentinian Dermatology, 48, 139-142.

Pimpinelli, N., Romagnoli, P., Bosi, A., Santucci, M., Mori, M., Guidi, S. \& Giannotti, B. (1993) Dendritic cells in the skin after allogeneic bone marrow transplantation: immunohistochemical and electron microscopic monitoring. European Journal of Immunology, 3, 310-317.

Ramsay, N.K., Kersey, J., Robinson, L., McGlave, P., Woods, W., Krivit, W., Kim, T.H., Goldman, A. \& Nesbit, M.E. (1982) A randomized study of the prevention of acute graft-versus-host disease. New England Journal of Medicine, 306, 392-397.

Talbot, D.C., Powles, R., Sloane, J.P., Rose, J., Treleaven, J., Aboud, H., Helenglass, G., Parikh, P., Smith, C. \& Rowley, M. (1990) Cyclosporine-induced graft-versus-host disease following autologous bone marrow transplantation in acute myeloid leukaemia. Bone Marrow Transplantation, 6, 17-20.

Thien, S.W., Goldman, J.M. \& Galton, D.G. (1981) Acute 'graftversus-host disease' after autografting for chronic granulocytic leukemia in transplantation. Annals of Internal Medicine, 94, $210-214$.

Thomas, E.D., Storb, R., Clift, R.A., Fefer, A., Johnson, F.L., Neiman, P.E., Lerner, K.G., Glucksberg, H. \& Buckner, C.D. (1975) Bonemarrow transplantation. New England Journal of Medicine, 292, 832-843.

Verdonck, L.F., Lokhorst, H.M., Dekker. A.W., Nieuwenhuis, H.K. \& Petersen, E.J. (1996) Graft-versus-myeloma effect in two cases. Lancet, 347, 800-801. 
Vogelsang, G.B., Jones, R.E., Hess, A.D., Geller, R.B., Schucter, L. \& Santos, G.W. (1989) Induction of autologous graft-versus-host disease. Transplantation Proceedings, 21, 2997-2998.

Weiden, P.L., Flournoy, N., Thomas, E.D., Prentice, R., Fefer, A., Buckner, C.D. \& Storb, R. (1979) Antileukemic effect of graftversus-host disease in human recipients of allogeneic marrow grafts. New England Journal of Medicine, 300, 1068-1073.

Weiden, P.L., Sullivan, K.M., Flournoy, N., Storb, R. \& Thomas, E.D. (1981) Antileukemic effect of chronic graft-versus-host disease. Contribution to improved survival after allogeneic marrow transplantation. New England Journal of Medicine, 304, 15291533.

Yeager, A.M., Vogelsang, G.B., Jones, R.E., Farmer, E.R., Altomonte, V., Hess, A.D. \& Santos, G.W. (1992) Induction of cutaneous graft-versus-host disease by administration of cyclosporine to patients undergoing autologous bone marrow transplantation for acute myeloid leukemia. Blood, 79, 3031-3035.

Yeager, A.M., Vogelsang, G.B., Jones, R.E., Farmer, E.R., Hess, A.D. \& Santos, G.W. (1993) Cyclosporine-induced graft-versus-host disease after autologous bone marrow transplantation for acute myeloid leukemia. Leukemia \& Lymphoma, 11, 215-220. 